\title{
The Study of Poverty as a Deterrent to Economic Development of Russia
}

\author{
Sergey A. Surkov ${ }^{1}$ \\ ${ }^{1}$ International Institute of Management LINK, Russia \\ Correspondence: Sergey A. Surkov, International Institute of Management LINK, Russia. E-mail: \\ context2002@yandex.ru or context2002@yahoo.com
}

Received: November 11, 2013

Accepted: January 15, $2014 \quad$ Online Published: February 25, 2014

doi:10.5539/ijef.v6n3p150

URL: http://dx.doi.org/10.5539/ijef.v6n3p150

\begin{abstract}
Article is devoted to an actual problem of poverty in Russia. Availability of poverty constrains economic development of Russia, because reduces economic activity of its inhabitants. Poverty separation by types is given. Based on surveys of different kinds dependencies poverty "poverty equation" built. The difference between the right and left parts of this equation shows the degree of social tension. Dependence of this tension on the time was obtained, and a comparison with significant events has been conducted.
\end{abstract}

Keywords: poverty, economic development, social tensions

\section{Introduction}

Poverty is widely discussed in the press, various researches pay much attention to fight against the poverty, special programs for fight against poverty are accepted, but clarity in this question isn't present. All the more difficult to announce the fight against poverty, if not very clear what it is. The question of influence of poverty on economic life remains an especially important, and its relevance increases if it is a question of Russia. The poverty level in Russia is difficult to establish, in contrast, for example, from Africa, where such a measure is $\$ 1$ per day. It is connected with that the problem "is smeared" because of collateral sources of the income, and also because of subsistence economies in the form of personal plots.

In addition, a living wage varies greatly for different regions of Russia. The last question should be the subject of a separate study. Russia is a poor country and its poverty is a traditional and hereditary because of the nature of the historical development of our country. The part of scientists considers poverty as a fight condition for existence which stimulates development of society and separately taken individuals. This approach is professed by liberals, and it is called Social Darwinism. Others see the social evil in poverty, calling for its elimination through more egalitarian distribution of wealth among the people. These ideas often are an attribute of vulgar socialism, but all in all it is rather Socio-egalitarian socialism.

\section{Literature Review}

Poverty data, on which the results of this paper are based, are inconsistent, that is connected with the political component of this issue. It is connected with policy of the authorities. They underestimate poverty level, and independent researchers overstate. Without the bringing of the polar estimates the picture will be incomplete. Therefore in the paper various data from different sources are given.

As Sergeyev and Limansky (2009) write, poverty has many negative consequences. First of all, it is necessary to consider that poverty is a factor of social tension. This is particularly important to consider in the conditions of economic crisis in Russia, burdened by the widely held view on obvious social injustice of modern life, since the moment of repartition of state ownership. The poor are fighting with unfair, in their opinion, distribution of property and the income connected with it. They gravitate to "restoration of justice", up to the commission of crimes and to violent methods of political struggle.

As history shows, it is the poor have always been "combustible material" social upheaval and sought to "rob the loot." For contemporary Russian situation is impossible to come up with a scenario worse than this.

As pointed out by Sergeev and Limansky (2009), the presence of the poor in society anyway brings economic and social losses. The poor man cannot fully participate in society, and his creativity is not disclosed and 
vanishes fruitlessly. "Inherited" poverty when children of poor people at identical abilities have much less chances to self-actualize, than their contemporaries who were born in families with normal income is especially dangerous. About this author wrote in reference (2006).

As pointed Aleksandrova (2001), now in practice almost all States alike have placed of the poor people considerable attention. In Belarus, as well as in other countries of the former USSR, long time poverty practically has not analyzed because of an ideological prohibitions. Poverty was recognized as an attribute of the stratified capitalist societies. The very phenomenon of poverty has been reduced up to its particular manifestation as temporary financial difficulties of low-income groups. According to A. B. Alexandrova, the modern period of development of the Belarusian economy is accompanied by emergence of considerable number of the new poor. The "new poor" it are the same vulnerable groups as the "old poor", in particular, these include children, senior citizens, women who are engaged in unskilled labor, the unemployed, the homeless and working poor.

Ukrainian President Viktor Yanukovych (2010) at the beginning of its activity has signed a decree "On urgent measures to overcome poverty". Overcoming and counteraction of poverty is considered the major priority in implementation of reforms in Ukraine.

Measures to introduce new mechanisms for the resumption of production, stimulating economic growth through social progress, the creation of decent work and for implementation during the crisis short-term measures of help to the most vulnerable segments of the population are listed in the list of tasks assigned to the Ukrainian government. In addition, the scheme reforming wage, social security, pension and health insurance, as well as the introduction of a mechanism to provide young professionals first job entrusted to develop to the government.

\section{Matherial \& Methods}

Whereas in Western Europe in modern times mainly negative attitude to the poor, who allegedly are themselves guilty of their misfortunes was formed, then in pre-revolutionary Russia poverty was seen as a grief, in which society is guilty rather than a specific individual. This interpretation of poverty as a product of an unjust social system contributed to the broad spread of socialist views.

In Soviet times, the concept of "poverty" is almost never used.

The concept of "needy" treats the situation so that people ostensibly simply divided into those who get income to a greater and lesser extent, it came into his shift. According to many researchers, in Post-Soviet Russia the mass impoverishment of the population occurred.

A sharp divergence between a data of State Statistics Committee and the data obtained by individual researchers largely depend on the definition of poverty. State Statistic Committee proceeds from definition of poverty through the cost of living by measuring absolute poverty. The same researchers, who give higher estimates of poverty, usually measure relative poverty.

If to analyze the change of the living wage by years, is possible to get the graph shown in Figure 1.

It would be desirable to compare level of a living wage with a rate of inflation, but the assessment of reliability of published data is so low that their use for certain will make this schedule unauthentic. 


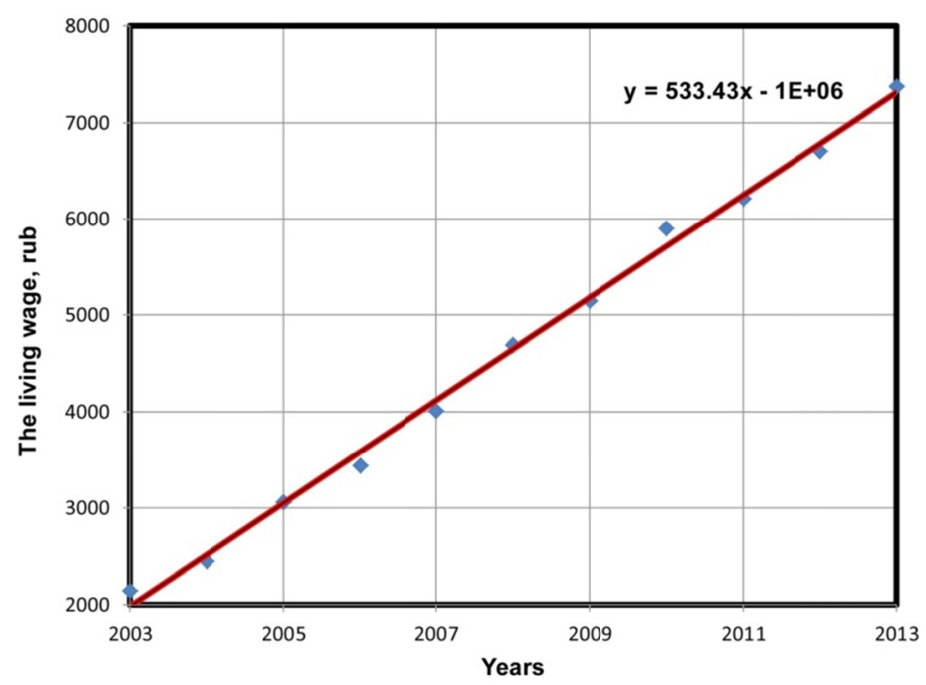

Figure 1. Changing the subsistence level in Russia by years

On Figure 1 the correlation coefficient equals 0.998 and is significant for all significance levels which exceed 0.01 . The regression equation has the form $\mathrm{y}=533.43 \mathrm{x}-1000000$.

Essentiality of correlation and the relatively high coefficient of slope show a steady and sustainable growth of subsistence level as compensator inflation for most unsecured people. This, in turn, has an impact on the proportion of the poor in society. If we fix this proportion as the relative number of people with an income below a certain level, as the State Statistical Committee does, it is possible to obtain the dependence shown in Figure 2.

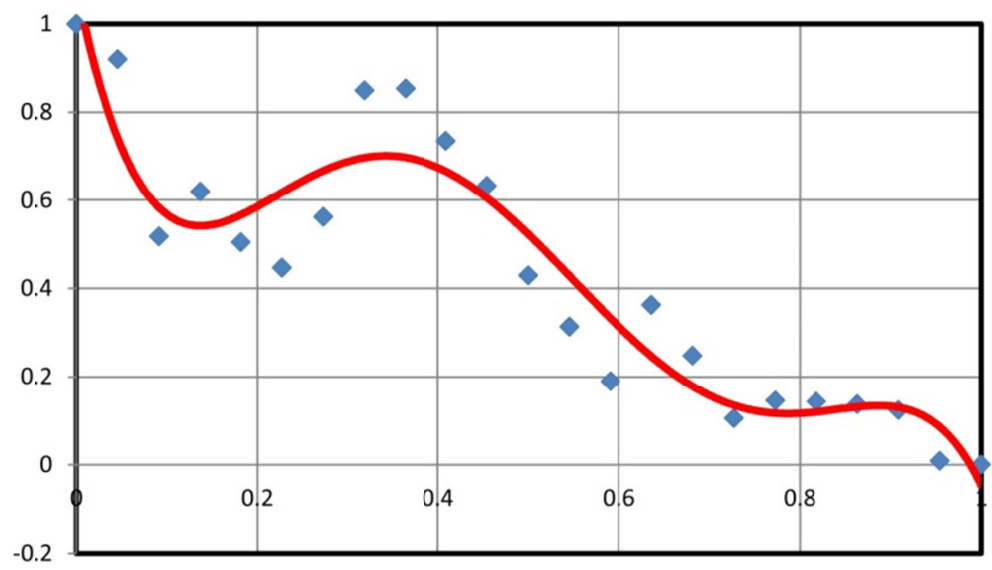

Figure 2. Changes in the level of poverty in Russia on the time

The graph in Figure 2 has a correlation coefficient of -0.833 which is an essential for all the significance levels exceeding 0.01 . The regression equation of the form $y=-0,0003 \mathrm{x}^{5}+3,2379 \mathrm{x}^{4}-12974 \mathrm{x}^{3}+3107 \mathrm{x}^{2}-310^{10} \mathrm{x}+$ $10^{13}$. In relative terms, this equation looks like as $y=-58,107 x^{5}+167,29 x^{4}-171,73 x^{3}+73,83 x^{2}-12,524 x$ $+1,237$. It is necessary to divide the whole equation by 100 to lead to the normal form, because data in the percentages was used when plotted.

Judging by the look of dependence and the trend shown in Figure 2, the proportion of poor people in Russia almost stabilized. This fact can't be considered positive because it means that the mechanism of socio-economic development "stalled", and the goal of economic reforms, carried out in Russia over the last two decades, was not reached.

According to Deripaska and Tambovtsev (2003), poverty inhibits the development of the domestic economy. The first of them points to the fact that in a country, where more than a third of the population lives below the poverty line, and the foundation of the economy is the resource sector, can't be sustainable development. In this case, 
priority should be given to solving social problems and sustainable development of the economy, its growth is in this context that it is no longer an end in itself but a means of objective and even the consequent solution of poverty issues. Tambovtsev (2003) notes that the smaller will be the poor, the more stable and better will be the life the country.

In general, the causes of poverty are different for different countries, and researchers have largely polar opinions. Latova (2010) points out that, according to some experts, there is a culture of poverty, a special culture, based on humility, inability to build their future and fatalism. In the process of primary socialization, these values are transmitted from one generation to another, thus leading to the "inheritance" of poverty.

There is also an explanation of poverty, which uses the concept of a culture of dependency, in which the source of poverty is the state with its social welfare programs.

Considered by many liberal scholars, these programs lead to the fact that the poor are no longer relies on their own strength and parasitize at the expense of society. This is the first group of factors.

Structural explanations which connect poverty existence with the structural features of society based on social stratification, an economic inequality, etc., can be considered as the second big group.

However, most likely cause and effect here traded places.

As already mentioned, the concept of poverty appeared in daily use of Russians with the transition to a market economy, but in fact in a previous era all residents, except the ruling elite, were actually poor.

However, this question takes on sufficiently exhilarating character on the background of significant growth in the ratio of income between rich and poor (Korop, 2005; Kommersant, 2005), as shown in Figure 3.

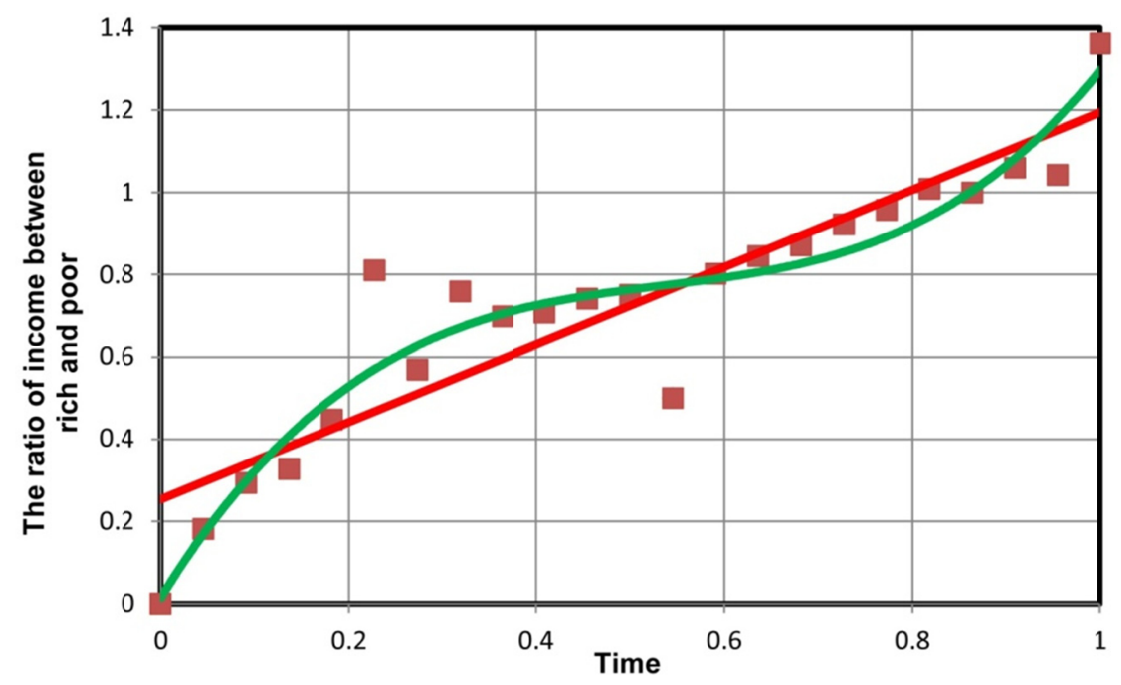

Figure 3. Changing the ratio of income between rich and poor in time

Red straight line shows the line of linear regression line, the green curve is the closest approximation to the experimental points.

The correlation coefficient for the dependence Figure 3 is equal to 0.88 , and is an essential for all significance levels exceeding 0.01 . These questions take on due to the need to accelerate economic development of Russia a special interest.

W. Easterly (W. Easterly New collectivism, 2009) indicates that economic success is determined by a huge number of factors, whose diversity and complexity dooms any attempts of planning to the defeat, and helps explain why economic success is impossible without economic freedom. But economic freedom can grow only gradually, and within society itself as a result of individual search by political and economic actors the most effective solutions to specific problems. "[For] transformation the whole societies, and output them out of poverty ... is required a gradual growth of economic freedom, which is based on processes already taking place inside the poorest countries."

On the Web site on poverty are given information that "...Poverty undermines the economy by upsetting the 
normal growth of human capital (education, professional experience, health) which is in theory the main driver of economic growth..." (Poverties.org). However, statistical data confirming the above information are not present.

The effects of poverty are most often interrelated so that one problem hardly ever occurs alone. For instance, bad sanitation makes it easier to spread around old and new diseases, and hunger and lack of water make people more vulnerable to them (poverties.org, 2011). Sufficient data on the actual impact poverty on the economy there also no.

E. Badger notes that, in accordance with its research over the course of the longitudinal study - which included 49 rural, white children of varying incomes - these same poor children were also exposed to chronic sources of stress like violence and family turmoil, or crowded and low-quality housing. Those kinds of stressors, the researchers theorize, may help explain the link between income status in childhood and how well the brain functions later on. That theory, they write, is consistent with the idea that "early experiences of poverty become embedded within the organism, setting individuals on lifelong trajectories."(Badger, 2013).

Research is of very great importance as opens one of the reasons of poverty and influence of poverty on economy. But from data of this work is not clear how one can apply this information for other countries.

As R. Grunewald indicated, "it makes sense that poverty rates are related to the overall health of the economy. As the economy grows, so do opportunities for employment and income growth. Stronger labor markets and higher income levels tend to help those families living in poverty move above the poverty threshold." (Grunewald, 2006). Here are also not enough specific data.

However, the development in Russia is constrained by substantial level of poverty for industrial country (Lenta, 2008).

20,9 million people were lived below the poverty line in the third quarter of 2007 , that is over 13 percent of the total population. At the same time the percentage of the poor in Moscow was even more due, in particular, of the cost of living in the capital which is much higher than the Russian average, and below the poverty line in Moscow were 23 percent of Muscovites. Furthermore, the income of the richest 10 percent of the capital's residents exceeds the income of the poorest 10 percent in 41.6 times.

According to Kalmatsky (2008), the percentage of the Russian population, whose incomes do not reach the subsistence level, was $13.4 \%$. This leads to the fact that a substantial part of the population is forced to save, including, and on balance of their diets (Anonymous, 2008). As point out experts of "Levada Center" only 18\% of Russians spend on food less than half of the family budget (Levada-Center, 2008).

Graphical representation of these data about spending for two decades is shown in Figure 4.

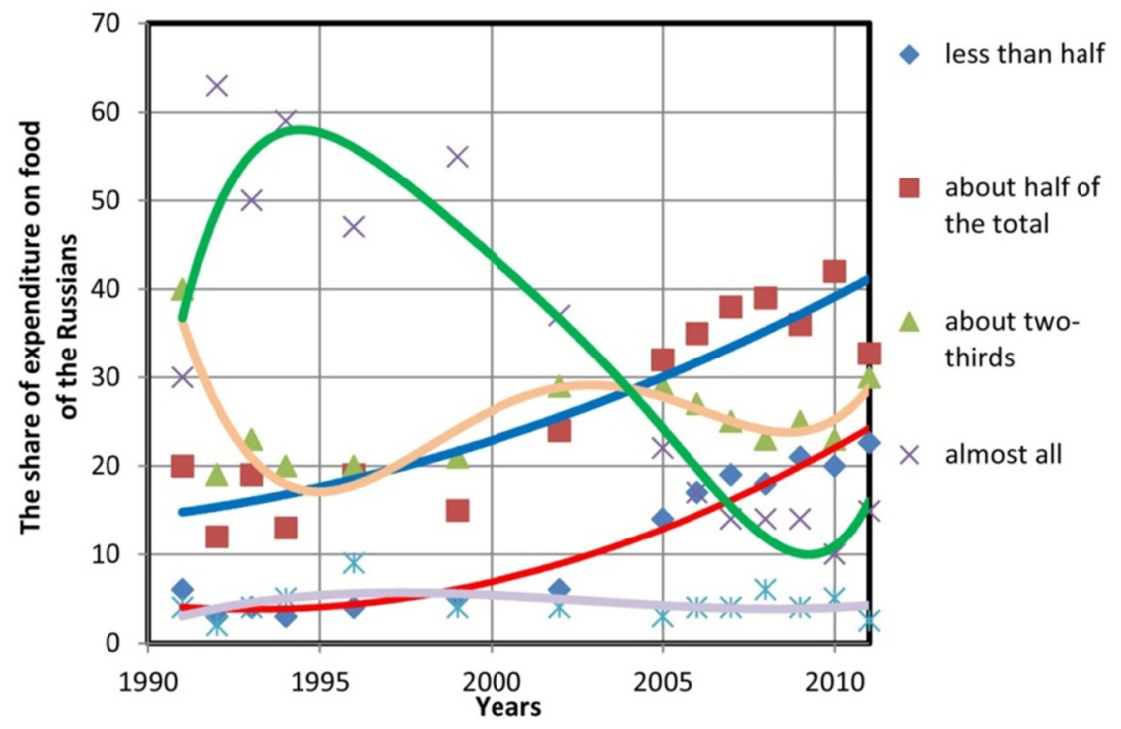

Figure 4. Change in the share of expenditure on food of the Russians by years 
Khokhlova (2007) indicates that in Russian society, there is a large number of problems directly related to moral, social, moral, cultural and ethical aspects of business relations, social responsibility and ethics in business. In her opinion polarization of society leads to deformation of its social structure - to the formation of "pyramidal" a bunk model (minority "rich" at majority "poor"), that inherent to the underdeveloped and backward countries.

Social structure of "diamond-shaped" form is typical for developed countries, which in addition to the rich and poor minorities, includes majority of developed middle class (for example, in the United States to this category belong almost $75 \%$ of the population).

The current division of society, regions and citizens destroys the unity of Russia, enhances inter-regional and inter-ethnic conflicts, leads to an outflow of highly qualified personnel abroad and worsens educational and professional potential of society. Economic and social disparities are inevitably accompanied by the loss of civic stances, by the distortion of the socio-ethical, moral and ethical landmarks, by loss of socially responsible behavioral attitudes of economic subjects. As is known, primordial aspiration of people to any activity including entrepreneurship, are based on the deep intrinsic motivation, which, acting like a tightly coiled spring, induces to activity, determines the choice of actions and deeds of the individual.

Unfortunately, far for all subjects seems necessary to commensurate personal aspirations with economic and social objectives of the society, of the market, of certain categories consumers. A real businessman, multiplying their property and developing their business, multiplies the country's national wealth, and this is the only way to really improve the economic situation of society.

Business for businessman that was selected by him as his personal vocation and given him money, is the meaning of his existence and moral duty. He serves him selflessly and unselfishly, and money is a decent reward for the executed mission.

Neschadin (2003) notes that, in his opinion, poverty in Russia in contrast to the poverty in the United States, Germany or France, threatens the strategic development of the country.

In terms of economy today Russia looks like a small country with a rather poor population. There is a danger that the political attitude to our country will change in accordance to its place in the global economy. The consequence of poverty has become a vicious circle: low purchasing power of society, low demand for goods and services, reduction of the domestic market, the low purchasing power of the population. According to A. Neshchadin, it is virtually impossible to break it without increasing the income of the population.

According to him, poverty reduces the quality of human resources, such as health and education. It adversely affects the motivation of labor and social activity of the population, without which the country's economic growth is unreal, and it constrains the necessary social reforms.

We are constantly in jeopardy that a more active implementation of reforms (transition to $100 \%$ payment utilities, partially paid medicine and education) can lead a lot of people already over the edge of poverty, and the whole society - to a pretty big trouble. The presence of poverty artificially overrides the possibility of vertical migration, even for talented people who might in the future become the elite of the country.

Poverty renders a "disarming" and "frigorific" impact on the activity of the people, besides from several positions. First, it provides a "bad start" without giving a knowledge, initial capabilities, understanding of the own future, etc. Secondly, it doesn't allow a person to outline "targets", "the trajectory of life development", since due to the limited vision of the world he can't imagine the complexity of reality, and existing development opportunities in this reality.

By following the above logic can be considered by poor people who spend all of their income on food. According official statistics their number is to $14 \%$ of the population (Ruvinskiy, 2008). But much more those, who spend on food overwhelming part of incomes, but are differ only slightly from the "actually" poor.

Because of the crisis, the number of Russians living below the poverty line has increased by 700.000 people - up to 19.7 million. This represents $14 \%$ of the total population of the country (Belyakov, 2010). These data refer to 2010. The aggregate of such people, in fact, holding back the development of society, as these people are not focused on the development, they are, with few exceptions, about such a possibility and do not knows.

The growth of differences between "rich" and "poor" negatively affects the development of the society not only and not so much due to differences in income, but also from the quantitative growth of the above-mentioned categories of the poor. Here it is necessary to make a digression and to note that it is not about the growth absolute or even of relative abundance the "poor", but about that she too is slowly declining compared to the needs of society. Society requires innovators, inventors, developers of new ideas in science, technology, 
management, people's daily lives, but "the poor people" in this work do not participate and can't participate due to lack of knowledge, skills and appropriate motivation. Therefore, the more "poor" (than slower reduced their number), the fewer fruitful and promising ideas are brought to "a market of general progress." Only education provides necessary guarantee that in the post-industrial society the family won't in misery.

Berezin (2010) writes that, according to his calculations, the total number of poor and very poor fell by about $10 \%$ and by the end of 2009 amounted to approximately 60 million people, or approximately on 6 million people less, than in the summer of 2008 .

Many scientists believe that substantial differences between rich and poor are a dangerous phenomenon. For example, Pankin (2009) indicates that the so-called "decile coefficient" defined as the ratio of the richest $10 \%$ and $10 \%$ of the poor, is in Russia, according to official figures is about 20 units, and estimated by various experts as about 30-40 units, as some researchers believe that it is even higher, especially in big cities. According to S. Pankin, if "decile coefficient" exceeds 10 units, the social system becomes "explosive."

This psychological condition causes declining interest in individuals to the work, the return on their activities falls that under current conditions an immediate has an effect on earnings and social status. This leads to the "worsening" adverse psychological state.

Accordingly, "a negative constituent" in relation of an individual to the work is incremented. The process becomes a "self-accelerating" with time that leads to a permanent increase in the probability of unfavorable development of the situation. On the one hand, there is a decline in the share of the poor people, on the other hand, the depth of the "fall" the recoil from working poor is increasing.

\section{Results}

Poverty in itself is a negative phenomenon, but its impact on the economic development of the country is much worse. Moreover, there are also induced phenomena. In particular, those who are intimately acquainted with the poor and observed in the details their vital activity, too, are experiencing the stress associated with it, and they are as the saying "losing heart". Negative impact on the economy of poverty consists not only in weakening of efficiency of activity of the poor people, but also in decreasing due to the transition into the category of the poor number of people active part of society.

If the share of the poor is $\mathrm{g}_{1}$, the share of dropping out from the active part of the population also $\mathrm{g}_{1}$, then the active part of the population will be $g_{2}-g_{1}$, where $g_{2}$ - the amount of active working population. If the recoil from the poor denote $h_{1}$, and the recoil from the active population $-h_{2}$, then economic losses will amount to $g_{1}\left(h_{2}-h_{1}\right)$ $+\mathrm{h}_{2}\left(\mathrm{~g}_{2}-\mathrm{g}_{1}\right)$. Level (share) of the poor varies as per the dependence shown in Figure 2, but the recoil from the poor also falls, because a wealth inequality grows according to the dependence in Figure 3. $y=-0,772 x^{2}+1,575$ $\mathrm{x}+0,136$.

A condition of poverty is diagnosed by different people in different ways. Some consider themselves middle class, being on the lowest rung of the social ladder, the others, being well-well off, forever dissatisfied by own well-being. The media are making not a little confusion, including in connection with the use not only different sources of information, but different scales. For example, very often especially publicly available media are used western classification, but to our society it is not very applicable by virtue of its different nature. In this regard, self-identification can be considered essential aspect of the problem poverty.

In other words, this means that the state of poverty is determining for formation of a special, of a negative psychological states. This state is formed in an individual under the influence of the settings, received during the life of knowledge and changing environmental conditions. Index of closeness the connection $\mu$ or the force of influence poor people on their surroundings can describe this condition. The value of this indicator depends on the moral and ethical standards of the surrounding society, and on the degree of "advancement" society by "post-industrial road". Increasing alienation of people from each other is one of the characteristics of this degree of "advancement".

This value of the index shows that the influence of poor exists on their surroundings, but the effect is not too significant.

As a result of the express survey of experts was able to determine the value of the coefficient $\mu$ at the current moment, and it was equal to 0.12 .

This indicator can be used to determine the importance of the poverty level for a given society. If it is below 0.1 , the effect of low, if the above, then, as the survey showed 76 managers, the impact of poverty in society is significant. 
As a result of influence the poor on the other workers the total losses to the economy will be higher and will be as follows: $g_{1}\left(h_{2}-h_{1}\right)+h_{2}\left(g_{2}-g_{1}\right)+\mu\left(g_{2}-g_{1}\right)$. If as a first approximation to consider that property stratification is the main reason for the decrease efficiency of activity of people with low incomes, it can be assumed that the performance of poor is inversely proportional to inequality measure. Then the dependence recoil of society on the time will be look as $\mathrm{G}=\left(-0,581 x^{5}+0,16729 x^{4}-0,171 x^{3}+0,073 x^{2}-0,012 x+0,001\right) /\left(-0,772 x^{2}+1,575\right.$ $x+0,136$ ).

Witness the life society, surveys and content analysis of four search engines Yandex, Mail, Yahoo and Rambler allowed to enter the following classification of real poverty in Russia:

- Beggary;

- Programmable poverty;

- Institutional poverty;

- Hidden poverty;

- Relative poverty;

- Imaginary poverty.

Beggary customary to mark for cases when absolute income is $\$ 1-2$ per day.

However the UN report on poverty problems (Human Development Report, 2010) was given a deeper interpretation, which defines marking of beggary by two indicators: low income and low budget of consumption.

To concretize the concept of beggary can also use the theory of the "potential well" (Gusev et al., 2006). Its essence lies in the fact that the individual is ensnared at adverse conditions, must find exit from them by overcoming certain social barriers. These barriers are the "walls" of "potential well". In this sense, can be considered as beggary a situation, where the individual can't to count to get out from "a potential well" during a period not exceeding expected by him interval or period of time during which he can tolerate such a state."

Programmable poverty determines the state of citizens who were "forced" to become or to be poor due to circumstances, which are programmed by someone. Government agencies, large and even small entrepreneurs, who derive some benefit from the presence of the poor of this category, can act in some cases as "programmers". In addition, important role played by, probably the desire to stand out from the environment, especially if only right now he come out from it.

Since the Russian reality doesn't allow talk about the overall improving the wellbeing, then, intuitively, these individuals create a group of people poorer than themselves.

Institutional poverty determined by the state of social institutions of society and accordingly, by opportunities of individuum to realize their individual needs. In this sense, the vast majority of Russian citizens are institutionally poor. The reason for this consists in that a social institution of medicine does not ensure them life and health, social institution of law enforcement agencies do not provide them with protection from criminal attacks, and as for the modern army then can doubt its ability to repel external threats.

Structural poverty as part of the institutional poverty, but accounted for separately, relates to the lack of mechanisms and structures to achieve a full-blown self-realization the citizens, especially those, who is in a condition of "bad start". Here this concept examines as the effects of birth in low-income families, difficulties in obtaining the required level of knowledge, lack of opportunities for learning and self-improvement, and similar initial restrictions.

Hidden poverty characterizes those who formal enrolled somewhere, gets let a small salary, but who have aggravating life the problems. Such problems include, for example, the lack of their own housing, permanent place of recreation, etc.

Relative poverty shows the differences in personal predilections. One of people has to spend a significant portion of income at more or less acceptable food, the other can't buy a car that attracted his, and the third can't build a large mansion. All of them consider themselves poor in relation to the subject matter of their needs.

Imaginary poverty distorts the overall picture, because people with income that hidden from taxation also fall under the definition of poor. Most often these are freelancers, persons with disabilities, who have retained the ability to work, residents of rural areas who earn additionally on the exploitation of natural resources of their region, etc. The presence of such people even more confuses the picture.

Constructing the equation what describes the patterns of an appearance and changing poverty, carried out as 
follows. At first was held a content analysis of all available sources on the subject, of placed on a solid support, i.e. books, magazine and newspaper articles. Thus obtained a list of the causes the appearance of poverty and the parameters affecting on it, was clarified during the re-analysis of Internet content sources using the four major search engines. Data were compared with each other, the list of factors influencing poverty was made, and in him were saved only matching positions. Further was held a semantic analysis, and were excluded most "exotic" and incredible factors, whose appearance in the list can be attributed, probably not a very high level of qualification or level knowledge of their authors. After that been held the ranking factors by the importance of by surveying twelve experts, and only factors included at the first dozen were kept in the list.

Further factors were divided into two groups: Causes and Effects. Types of poverty listed in the above classification were attributed to the Effects, other factors were attributed to the Causes. For these two groups were made up two questionnaires with decimal scale of scores. It was done in order to avoid comparison of factors from two lists by experts. Questionnaires were offered to group of 132 experts with an interval of two weeks. According to the author, it was enough, given the stressful pace of life and the number of events in the life of each of the experts, so that answers to questions from the first questionnaire were erased in their minds, and undesirable chain of logic was not formed. This method is applied for the objectification of the results, since, otherwise, should expect to receive the averaged of expert opinions on the mechanisms of formation of poverty, but in this study, this problem has not been posed.

Questions in the questionnaire concerned the changes of indicators poverty and factors causing these changes, in time, since it is these trends are interesting from socio-economic positions. Meanwhile, dependencies on the time included not in full to the obtained equation. It points to its static nature and the possibility in the future to find the dynamic equation, which is likely to be able to describe found regularities more accurately. A comparison of the above-described manner temporal trends shows that they have a similar appearance, as shown in Figure 5.

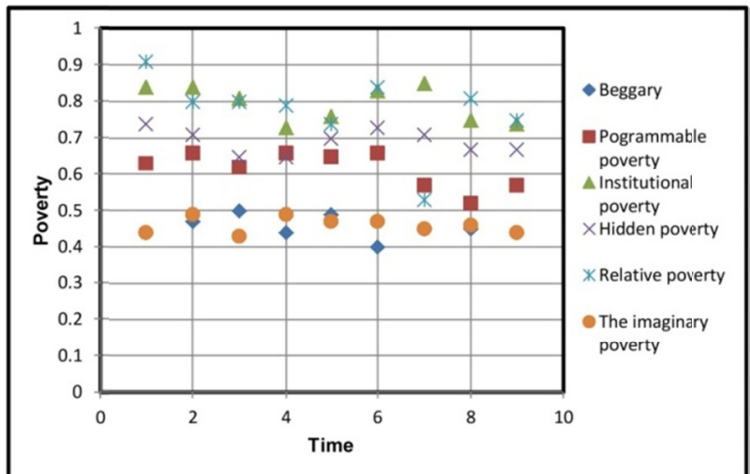

a)

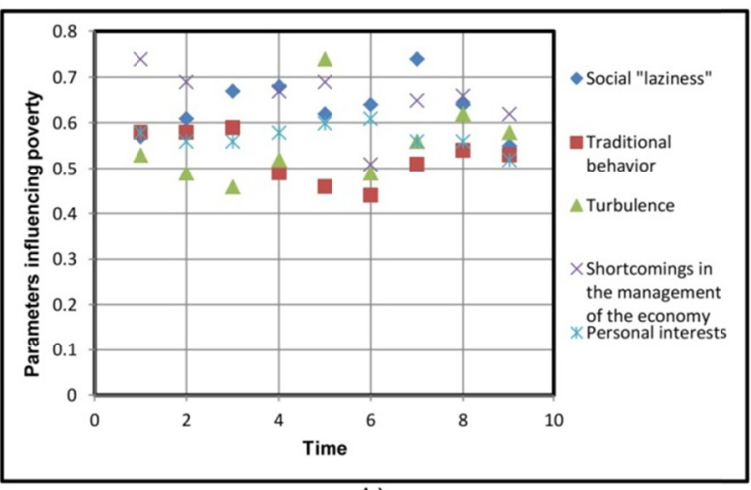

b)

Figure 5. Dependence of the dimensions of poverty from time. a) poverty, b) parameters influencing poverty

Based on these trends were built dependences parameters of poverty from time.

These dependencies are used further in the analysis of poverty, for that was built the "poverty equation". "Poverty equation" (1) can be written as an additive expression for the following reasons. The left side can be written as a sum, since the sets of citizens belonging to the above categories, practically don't overlap.

The right side of the equation obeys more complex laws, and in reality is clearly observed the interaction of its constituent factors. As a first approximation one can neglect by these terms of the equation.

$$
U_{N}+U_{P}+U_{I}+U_{S}+U_{O}-U_{M}+D_{o}=\partial G / \partial t+T_{R}+L_{S}+Y_{T}+A_{N}+M_{L}
$$

where:

$\mathrm{U}_{\mathrm{N}}$ - level of poverty,

$\mathrm{U}_{\mathrm{P}}$ - level of programmable poverty,

$\mathrm{U}_{\mathrm{I}}$ - level of institutional poverty,

$\mathrm{U}_{\mathrm{S}}$ - level of hidden poverty,

$\mathrm{U}_{\mathrm{O}}$ - level of relative poverty, 
$\mathrm{U}_{\mathrm{M}}$ - level of imaginary poverty,

Do - "residual" level of poverty - the lowest possible level of poverty,

$\partial \mathrm{G} / \partial \mathrm{t}$ - changing social conditions, in particular, a measure of change recoil,

$\mathrm{T}_{\mathrm{R}}$ - traditional economic behavior,

$\mathrm{L}_{\mathrm{S}}-\ll$ «social laziness»,

$\mathrm{Y}_{\mathrm{T}}$-level of turbulence in the socio-economic life,

$\mathrm{A}_{\mathrm{N}}$-level of deficiencies in the management of the economy,

$\mathrm{M}_{\mathrm{L}}$ - is availability of personal interests of people in society that impede poverty reduction.

The difference between the left and right sides is a probability of occurrence of social unrest. In the case of negative values this means the emergence of social upheavals initiated by poverty.

$$
W_{s}=U_{N}+U_{P}+U_{I}+U_{S}+U_{O}-U_{M}+D_{o}-\left(\partial G / \partial t+T_{R}+L_{S}+Y_{T}+A_{N}+M_{L}\right)
$$

When using the results obtained above time dependences expression (2) has the form, which allows you to get the graph shown in Figure 6.

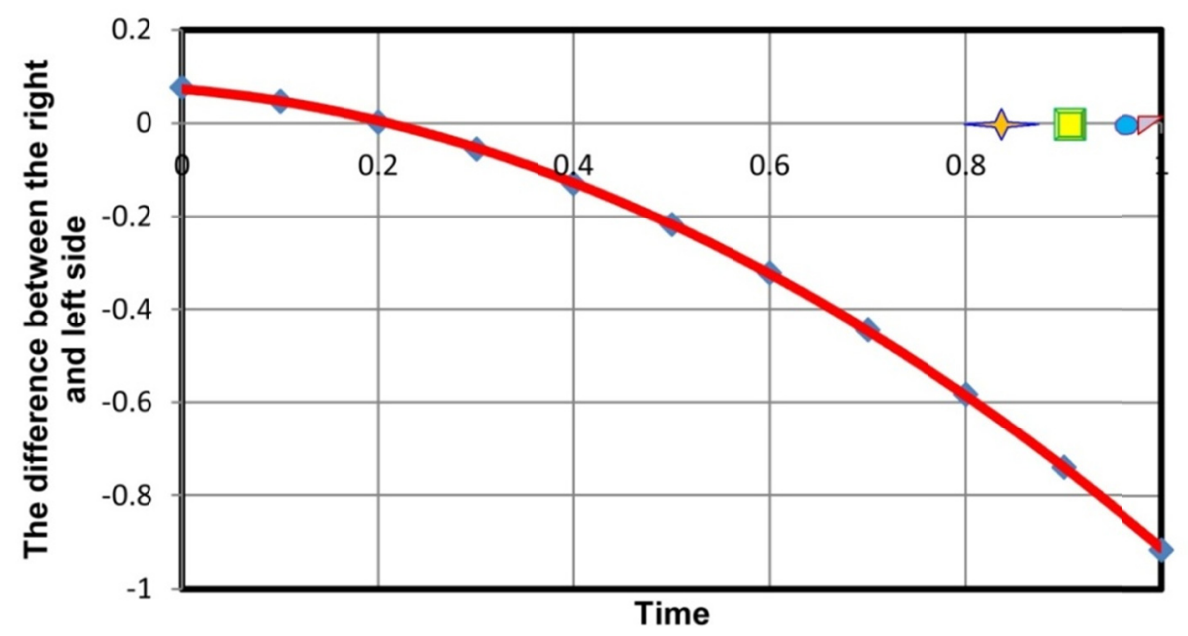

Figure 6. Dependence of the difference between the right and left sides of the equation from time

$\checkmark$-Events on Manezh Square;

-Confrontation at Bolotnaya Square;

0 -Riots in Biryulyovo;

$\nabla$-The excitement of fans at a football match in Yaroslavl.

\section{Conclusions}

From the graph in Figure 6 it is visible that the tensions related to issues of poverty, can be associated with manifestations of spontaneous national excitements.

The poverty problem in Russia has multilateral character and in many respects is defined by approach of people to this question. However, it is clear that its existence reduces possibilities of economic development of the country.

Easy to see, according to the logic of occurring events, that hopelessness and uncertainty about the future, stemming from poverty, provoke spontaneous protests. These spontaneous protests not only bring direct economic losses, but they also cause deterioration of the psychological climate in society. In turn, this aggravation leads to a decrease efficiency of the staff of companies, and thus lower to productivity of their labor.

Study of various constituting poverty and countering devastating impact those constituents will help stabilize the economic and social situation in Russia.

\section{References}

Aleksandrova, A. B. (2001). Scales of poverty among women of the Republic of Belarus: Results of the survey. The report. Minsk. Retrieved from http://www.owl.ru/content/library/books/p1861.shtml 
Badger, E. (2013). The Lasting Impacts of Poverty on the Brain. Place Matter. Retrieved from http://www.theatlanticcities.com/jobs-and-economy/2013/10/lasting-impacts-poverty-brain/7377/

Belyakov, E. (2010). Every seventh is below the poverty. Retrieved from http://digest.subscribe.ru/economics/society/n205147749.html

Berezin, I. (2010). New style of middle-class life. The Expert, 4(690).

Easterly New Collectivism. (2006). At the core of the international fight against poverty lies the ideology of the "new collectivism". Kommersant, 168, 11.

Grunewald, R. (2006). The connection between poverty and the economy. Fedgazette. Regional Business and Economics Newspaper 1 November. The Federal Reserve Bank of Minneapolis. Retrieved from http://www.minneapolisfed.org/publications_papers/fedgazette/

Gusev, A. V., Surkov, S. A., Boiko, Y. P., Putin, M. E., Lukashev, A. M., \& Hrupalov, A. A. (2006). Motivation of staff in the condition of presence a "potential well" in society. Human Resource Management, 3, 54-60.

Human Development Report. (2010). The Real Wealth of Nations: Pathways of human development (pp. 244). ABM UN. Publishing "All the world".

Kalmatsky, M. (2008). Who Lives bad. Income of every seventh citizen of the Russian Federation does not even reach the poverty line. Novye Izvestia.

Khokhlova, T. P. (2007). To serve the Cause or the Money? Management in Russia and Abroad, 3, 130-134.

Kommersant. (2005). Crisis pulls together rich and poor. Stratification of the population by income in Russia temporarily slowed. Kommersant, 138(4193).

Korop, E. (2005). Poor Avengers. All-Russian Public Opinion Research Center. Retrieved fom http://www.profile.ru/items_11855

Latova, N. (2010). Poverty. Online Encyclopedia Krugosvet. Retrieved from http://krugosvet.ru/enc/gumanitarnye_nauki/ekonomika_i_pravo/BEDNOST.html

Lenta, R. (2008). In Russia counted over 20 million poor people. Retrieved from http://seclub.org/lenta/view/64486/

Lenta, R. (2010). Yanukovych signed a decree on combating poverty. Retrieved from http://korrespondent.net/business/1051598-yanukovich-zayavil-chto-podpisal-ukaz-napravlennyj-na-borbus-bednostyu

Neshchadin, A. (2003). Poverty: The Economics of mistrust. Vedomosti, 205(1005).

Nutrition Russians. (2008). Levada-Center. Retrieved from http://www.levada.ru/press/2008080704.html

Orehin, P. (2003). Poverty of population hinders the development of the domestic economy. Ready recipes for solving this problem, experts do not yet see. Nezavisimaya Gazeta, 73-74.

Pankin, S. (2009). Death of the leader of Russian collaborationists. The informational-analytical portal Eurasia. Retrieved from http://evrazia.org/article/1191/

Position. (2008). Only would not stay hungry. Many families are forced to limit themselves in food. Council of Trade Unions Federation of Tver, 32(1079), 20-26.

Poverties. (2011). Causes \& Effects of Poverty On Society, Children \& Violence. Retrieved from http://www.poverties.org/effects-of-poverty.html\#sthash.SaMyXwsO.pdf

Poverties. (2011). Poverty in the United States Social Welfare vs the Market. Research for social and economic development. Retrieved from http://www.poverties.org/poverty-in-the-united-states.html

Ruvinskiy, B. (2008). Half of Russians don't have enough money for food. Business Network RB. RU. Retrieved from http://www.rb.ru/topstory/economics/2008/05/16/165212.html

Sergeyev, M., \& Limansky, M. (2009). Paradoxical poverty of Russia in crisis. The amount of material unsecured citizens today than there was in the "fat" years 2005 and 2006. Nezavisimaya Gazeta, May 29.

Surkov, S. A. (2006). Application of sociomechanics to develop economic strategies. Part 1. Economic Strategies, 4(46), 111-117.

Surkov, S. A. (2006). Application of sociomechanics to develop economic strategies. Part 2. Economic Strategies, 5-6(47-48), 145-151. 


\section{Copyrights}

Copyright for this article is retained by the author(s), with first publication rights granted to the journal.

This is an open-access article distributed under the terms and conditions of the Creative Commons Attribution license (http://creativecommons.org/licenses/by/3.0/). 